\title{
Revenue Allocation and the Quest for Economic Development in Nigeria
}

Francis A. Oluleye", Kunemoemi Zacchaeus

Department of Economics and Development Studies, Federal University of Otuoke, Bayelsa State, Otuoke, Nigeria

*Corresponding author: Francis A. Oluleye

\section{Abstract}

The main goal of economic development is to improve the quality of life of the people of the country and getting them out of abject poverty. To achieve this laudable goal, enormous resources are required. Where a nation operates a federal system of government having more than one level of government such as Nigeria, available national resources need to be shared among the various levels to enable each level discharge its constitutional functions. In Nigeria, like other federated nations, revenue generating and expenditure powers are shared among the three levels of government. The nation's revenue sharing formula has been reviewed several times to keep pace with economic and political realities of the nation. Unfortunately, there has been so much discontentment with the various revenue sharing formulae on the ground that they have not met the development needs of the various regions of the country. As a result, people have not only called for a re-review of the current formula but are also calling for resources control and the restructuring of the nation in terms of economic and political. This paper examines the issues with revenue allocation formula in Nigeria and how to make the formula more responsive to the development need and aspirations of the people and to achieve the goal of poverty eradication and improving the people's standard of living.

Keywords: Federalism, Revenue allocation formula, Inter-governmental relations and Economic development.

Copyright @ 2019: This is an open-access article distributed under the terms of the Creative Commons Attribution license which permits unrestricted use, distribution, and reproduction in any medium for non-commercial use (NonCommercial, or CC-BY-NC) provided the original author and source are credited.

\section{INTRODUCTION}

At independence in October 1960, the nation operated the Parliamentarian system of government, although unitary structure was established in 1914. From 1914 the various constitutional changes contributed to the setting up of a firm foundation for a federal structure. Sir Arthur Richard who succeeded Bernard Bordello as the Governor-General in 1939 was also instrumental to the foundation of federalism in Nigeria. The unitary structure established in 1914 gradually transformed into a three regional structure with a weak central government in 1960, four regions in 1963, 12 states in 1967, 19 states in 1969, 23 states in 1987 and 30 states in 1991. In 1996, the nation became 36 states and Federal Capital Territory (FCT) Abuja ith 774 local government councils.

Currently, the federal government takes 52.68 percent, the states 26.72 percent and the local governments, 20.60 percent with 13 percent derivation revenue going to the oil producing states.

This formula indicates that federal government takes more than fifty percent of the entire revenue accruing to the nation. Although there is a little reduction in the share of the federal government when compared with what was obtained in 1977 when it shared 57 percent. Over the years, Nigerian people have expressed dissatisfaction with the revenue sharing formula, particularly the vertical formula for several reasons. These reasons include:

- It is believed that the federal government is unnecessarily being enriched at the expense of other levels of government

- The shares of state and local governments in the nation's revenue are not commensurate with their fiscal functions and responsibilities.

- The formulae have not adequately catered for the plight of the areas and regions where the revenues are generated.

- The formulae have not specifically addressed the development challenges of certain regions of the countries

- The formulae have continued to encourage corruption in terms of embezzlement and misappropriation of funds at the federal level 
- The state and local governments that are closer to the people and know their plight are starved of the needed resources to ameliorate the people's plight.

As a result of this dissatisfaction, the people have called for regional control of endowed resources. Although, it must be admitted that the implementation of resources control arrangement is a very complex one, it is believed by the proponents, agitators and supporters of this position that it is the only way to enhance rapid economic development and reduce the poverty level.

The question of an acceptable formula for revenue allocation among the component tiers of the Nigerian nation has begged for answer for decades now. The quest to have acceptable formula for sharing the nation's revenue has led to the formation of various commissions, committees, decrees and executive orders to correct the imbalance in the revenue allocation. Some of these commissions, committees and decrees includes: Sydney Philipson commission of 1946, HicksPhillipson Commission of 1951, Louis-Chick Commission of 1953, Raisman-Tress Commission of 1958, Binn Commission of 1964, Dina Commission of 1969, Aboyade Technical Committee on Revenue Allocation of 1977, Okigbo Commission of 1980 , Danjuma Commission of 1989, Decree No. 15 of 1967, Decree No. 13 of 1970, Decree No. 9 of 1971, Decree No. 6 of 1973, Decree No 36 of 1984 with various Act of parliament before adopting the current revenue allocation formula in March, 2004..

It is based on these discontenting factors that this paper examined the issues with revenue allocation formula and the quest for Economic development in Nigeria.

\section{LITERATURE REVIEW \\ Revenue Allocation Formula}

The two revenue allocation formulae used in Nigeria are the vertical allocation formula (VAF) and the horizontal allocation formulae (HAF). The vertical Allocation formula is applied vertically to the total volume of disbursable revenue in the Federation Account at a particular point in time and it shows the percentage allocated to each of the three tiers of government i.e. federal, states and local governments. The VAF also allows every tier of government to know what is due to it; the Federal Government on one hand and the 36 States and 774 Local Governments on the other $[1,2]$. The Horizontal Allocation Formula is used to share the revenue allocated to the states among the states and among the local government areas. The horizontal formula is based on identified criteria. Through the application of the horizontal allocation formula principles, the allocation due to each State or Local Government is determined. Thus, the vertical allocation formula is for inter-tier sharing among the three tiers of government while the horizontal allocation formula is for intra tier sharing among the 36 States and the 774 Local Governments in Nigeria $[2,1]$.

There are constant criticisms and agitations against the present federal practice which also helped in promoting the call for practical fiscal federalism. It is pitiable to surface that the deplorable state of fund distributable to the States and local governments in Nigeria and added with the

\section{Institutional Framework and Components for Revenue Allocation in Nigeria}

The evolution of revenue allocation in Nigeria has pass through different phases in the country's history and the need to have a strong fiscal federalism as a veritable tool for development has been a contentious issue for a long time. In an attempt to address the contentious issue with fiscal federalism and the quest for economic development in the country has led to the formation and pronouncement of various Revenue Allocation Commissions, Committees, Degrees and Acts and Executive orders.

The current Revenue allocation in Nigeria has two components: The Vertical and Horizontal revenue allocation. The vertical Revenue Allocation Formula (VAF) is applied vertically to the total volume of disbursable revenue in the Federation Account distributable pool at a particular point in time. It allows each tier of government to know what is due to it; the Federal Government on one hand and the 36 States and 774 Local Governments on the other. For instance, the Federation Accounts Allocation Committee (FAAC) allocated $\$ 619.857$ billion to the three tiers of government in March, 2019 which was generated in February, 2019. This was inclusive of the $13 \%$ derivation revenue for oil producing states and the $11 \%$ cost for revenue generating agencies. See break down for March, 2019: Federal Government received \#257.681 billion, States received $\$ 169.925$ billion, Local Government Areas received 127.722 billion, Oil Producing States received $\$ 50.946$ billion while the cost for revenue generating agencies received 13.582 billion as cost for revenue collection. In April, 2019, just about a week ago, the Federation Accounts Allocation Committee (FAAC) also allocated $\$ 617.566$ billion to the three tiers of government in April, 2019 which was generated in March, 2019. This was inclusive of the $13 \%$ derivation revenue for oil producing states and the $11 \%$ cost for revenue generating agencies, transfers and FIRS Refund. See break down for April, 2019: Federal Government received $\$ 257.758$ billion, States received $\$ 168.254$ billion, Local Government Areas received 126.575 billion, Oil Producing States received $\$ 49.823$ billion while the cost for revenue generating agencies received N15.156 billion as cost for revenue collection, transfers and FIRS Refund [3]. The Horizontal Revenue Allocation Formula (HAF) is specifically applicable to 
state and local government. It enables the state and local to know the basis for sharing of the volume of revenue already allocated to the 36 states and 774 local governments.
The table below shows the institutions and their role in revenue allocation in Nigeria.

Table-1: Institutions and their Roles in Revenue Allocation in Nigeria

\begin{tabular}{|l|l|l|}
\hline S/N & Institutional & Role \\
\hline $\mathbf{1}$ & $\begin{array}{l}\text { Revenue Mobilization, } \\
\text { Allocation and fiscal } \\
\text { Commission }\end{array}$ & $\begin{array}{l}\text { Monitor revenue accruals into and disbursements from the federation } \\
\text { account. It therefore determines the allocation indices }\end{array}$ \\
\hline $\mathbf{2}$ & Central Bank of Nigeria & A custodian of the federation account \\
\hline $\mathbf{3}$ & $\begin{array}{l}\text { Federation Accounts } \\
\text { Allocations Committee }\end{array}$ & $\begin{array}{l}\text { It determined monthly disbursement from the federation account. It } \\
\text { comprises of representative of the federal, 36 states government, RMAFC, } \\
\text { OAGF and other revenue agencies etc. }\end{array}$ \\
\hline $\mathbf{4}$ & $\begin{array}{l}\text { State Joint Local } \\
\text { Government Account }\end{array}$ & $\begin{array}{l}\text { It determines monthly disbursement from the State Joint Local Government } \\
\text { Account. It comprises of representatives of the State and local governments }\end{array}$ \\
\hline
\end{tabular}

Source: Kabir A Bashir [4], Workshop paper

\section{An Overview of Revenue Allocation Formula in Nigeria from 1946 to date}

This section discusses the various revenue allocation formulae from 1946 to date. It highlights the vertical and horizontal revenue allocation formulae and also looks at the derivation principle. Table-2 and Figure-1 contained the revenue allocation of the 1946 Phillipson' commission's recommendation. Note that all figures in each of the tables and graphs are presented in percentages.

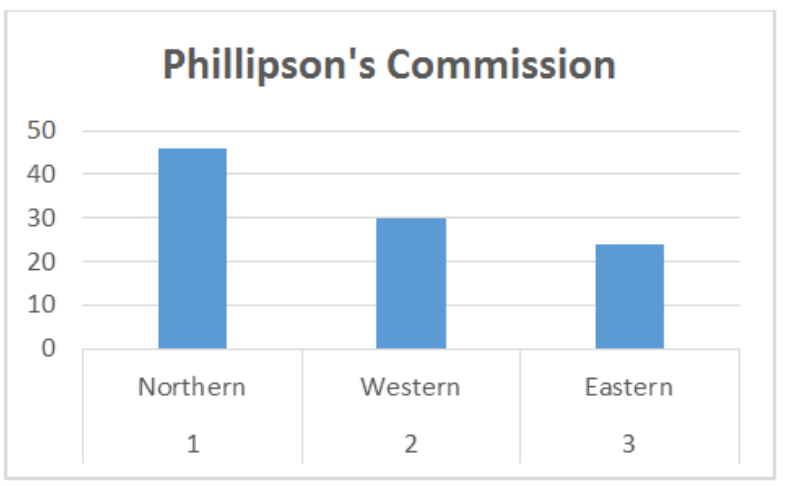

Fig-1: 1946 Phillipson Commission Source: Nwidum, 2011 [5]

Table-2: 1946 Phillipson Commission

\begin{tabular}{|l|l|l|}
\hline S/N & Region & Revenue Percentage \\
\hline 1 & Northern & 46 \\
\hline 2 & Western & 30 \\
\hline 3 & East & 24 \\
\hline
\end{tabular}

As shown in the graph above, the Commission adopted two revenue allocation principles: derivation and even development. The commission advocated for proportionate regional expenditure to their contribution and also to the total federal non-declared revenue. This recommendation has made the north to have a higher allocation base on the overriding derivation principle. However, the 1951 Hicks-Phillipson commission recommends revenue allocation based on derivation, need and national interest while the 1953 Lious Chick commission recommends revenue allocation based on derivation and fiscal autonomy. It was the 1953 commission that prompted for fiscal autonomy even before independence to enable regions to administer an effective governance for development. The RaismanTress's Commission based revenue allocation on derivation, Fiscal autonomy and United Nation Policy and recommended that $30 \%$ of mining rents and royalties be paid into the Distributable Pool Account (DPA) in the ratios as contained in Table- 3 and Figure2.

Table-3: 1958 Raisman-Tress's Revenue Commission

\begin{tabular}{|c|l|l|}
\hline S/N & Regions & Percentage \\
\hline 1 & Northern & 40 \\
\hline 2 & Western & 31 \\
\hline 3 & Eastern & 24 \\
\hline 4 & Southern Cameroun & 5 \\
\hline
\end{tabular}

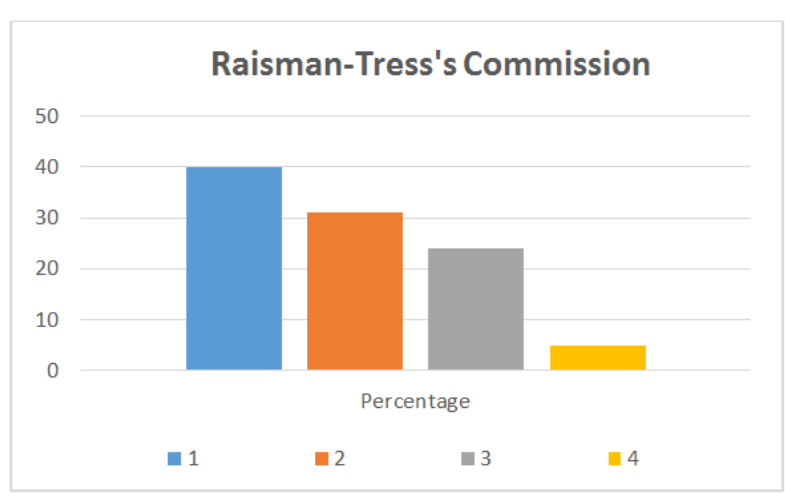

Fig-2: The 1958 Raisman-Tress's Commission Source: ICAN (2014) [6]

The Binn's commission revenue allocation was based on comparable financial responsibility for each Regional Government, needs and Paramount financial autonomy for Federal Government. However, in 1961 the Southern Cameroun left Nigeria and the Distributive Pool Accounts was redistributed as follows: Northern 42, Eastern 33 and Western 25. Later 
in 1963, the creation of Mid-Western region prompted the commission to recommend that the percentage due to the western region should be shared in the ratios of 3:1 [7]. Distribution from the distributable Pool Account (DPA) is shown on table 4 and figure 3 below.

Table-4: 1964 Binn Commission

\begin{tabular}{|l|l|l|}
\hline S/N & Regions & Percentage \\
\hline 1 & Northern & 42 \\
\hline 2 & Eastern & 30 \\
\hline 3 & Western & 20 \\
\hline 4 & Mid-Western & 8 \\
\hline
\end{tabular}
2018 [9]

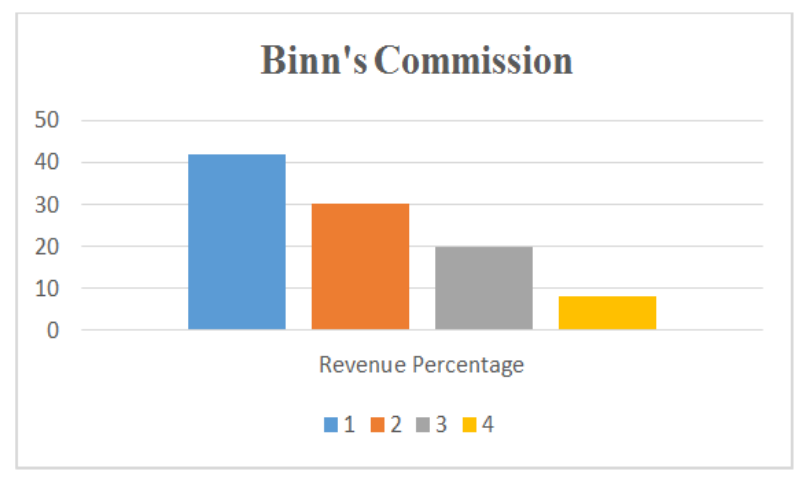

Fig-3: Revenue allocation based on 1964 Binn Commission

Decree No.15 of 1967 created the 12 states in Nigeria and usher in a new constitutional provision for revenue allocation. The new revenue allocation abandoned the previous criteria that would have help the nation's federalism towards fiscal federalism for economic development. See table-5 below:

Table-5: Revenue Allocation to Regions/State based on Decree No 15 of 1967

\begin{tabular}{|l|l|l|}
\hline S/N & Regions/States & Revenue Percentage \\
\hline 1 & East Central & 17.5 \\
\hline 2 & Lagos & 2 \\
\hline 3 & Mid-Western & 8 \\
\hline 4 & 6 Northern States & 7 \\
\hline 5 & Southern Eastern & 7.5 \\
\hline 6 & Rivers & 5 \\
\hline 7 & Western & 18 \\
\hline \multicolumn{2}{|c|}{ Source: Patrick, 2018 [9] }
\end{tabular}

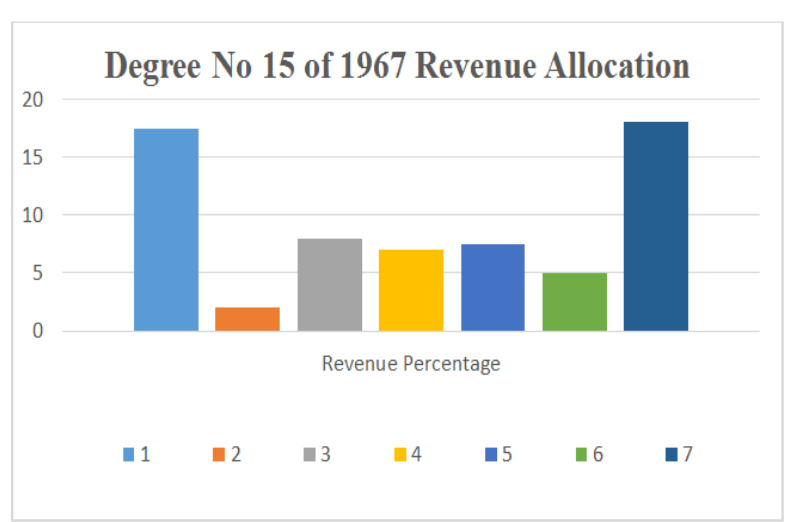

Fig-4: Revenue allocation based on Decree No 15 of 1967

Decree No 15 of 1967 allocated only $65 \%$ to the 12 states while $35 \%$ was reserved by the federal government for security and social infrastructural development. The Degree undermined the previous criteria for revenue allocation which inadvertently hindered economic development in the newly created states. The Dina Commission of 1968 recommendation for revenue allocation was based on derivation, basic needs, minimum national standards and balance development [6]. The commission also recommended that the distributable pool account should be rename States Joint Account (SJA). However, the recommendations were rejected by the Military Government, though some of its recommendations were later on adopted in piece meal.

The 1977 Aboyade revenue allocation commission explicitly define the vertically and horizontal allocation criteria among the three tiers of government and the special funds provision, though, the constituent Assembly of 1978 rejected the report because it was belief that the report was too technical to adopt. However, from the 1999 constitution, the 13 percentage derivation provision was accounted for before the revenue is allocated into the federation account. Table 6 and 7 contained the 1977 Aboyade commission's recommendation till March, 2004 modified grant from the federal Ministry of Finance (FMF).

Table-6: 1977 Aboyade Commission till 1992 (January)

\begin{tabular}{|c|c|c|c|c|c|}
\hline Items & $\begin{array}{l}1977 \text { Aboyade } \\
\text { Commission }\end{array}$ & $\begin{array}{l}1979 \text { Okigbo } \\
\text { Commission }\end{array}$ & $\begin{array}{l}1981 \text { Revise } \\
\text { Act }\end{array}$ & $\begin{array}{l}1984 \\
\text { Till } 1991\end{array}$ & $\begin{array}{l}1992 \\
\text { (January) }\end{array}$ \\
\hline Federal Government & 57 & 53 & 55 & 50 & 50 \\
\hline State & 30 & 30 & 30.5 & 30 & 25 \\
\hline Local Government & 10 & 10 & 10 & 15 & 20 \\
\hline Special Funds & 3 & 7 & 4.5 & 5 & 5 \\
\hline
\end{tabular}

Source: ICAN, 2014 [6]; Patrick, 2018 [9] 
Table-7: 1992 (June) till March 2004, Modified Revenue Allocation Formula from Federal Ministry of Finance (FMF)

\begin{tabular}{|l|l|l|l|l|}
\hline Items & $\begin{array}{l}\text { 1992 June to April } \\
\mathbf{2 0 0 2}\end{array}$ & $\begin{array}{l}\text { 2002 (May) } \\
\text { 1st Executive } \\
\text { Order }\end{array}$ & $\begin{array}{l}\text { 2002 (July) } \\
\text { 2nd Executive } \\
\text { Order }\end{array}$ & $\begin{array}{l}\text { 2004 (March) Modifi } \\
\text { from FMF }\end{array}$ \\
\hline $\begin{array}{l}\text { Federal } \\
\text { Government }\end{array}$ & 48.5 & 50 & 54.68 & 52.68 \\
\hline State & 24 & 30 & 24.72 & 26.72 \\
\hline $\begin{array}{l}\text { Local } \\
\text { Government }\end{array}$ & 20 & 15 & 20.6 & 20.6 \\
\hline Special Funds & 7.5 & 5 & 0 & 0 \\
\hline
\end{tabular}

From Table-2 of the 1946 Phillipson Commission's Recommendation to Table-7 of the 2004 modified grants from the Federal Ministry of Finance (FMF), showed the vertical revenue allocation formula among the regions/states. It is pertinent to note that government has followed a shifting formulas to achieve a reliable fiscal federalism for economic development but this is still far fetch.

The Horizontal Revenue Allocation Formula (HAF) is specifically applicable to states and local government areas. It enables the state and local government to know the basis for sharing of the volume of revenue already allocated to the 36 states and 774 local governments. The HAF is based on the following criteria contained in table 8 above: equality of states, population, equal access to development opportunities, national minimum standard, absorptive capacity, independent revenue efforts, fiscal efficiency, social development and primary school enrolment and landmass and terrain. The rational for each of these factors has generated heated debates over the years. It is on this note that the paper tends to also want to highlight revenue allocation based on derivation principle which has not been given serious attention. Table- 8 contained the horizontal revenue allocation formula among regions and state over time.

Table-8: Horizontal Vertical Revenue Allocation from Pre-1964 to date

\begin{tabular}{|l|l|l|l|l|l|}
\hline Criteria/ Principles & $\begin{array}{l}\text { Pre- } \\
\mathbf{1 9 6 4}\end{array}$ & $\begin{array}{l}\mathbf{1 9 6 4 -} \\
\mathbf{1 9 7 6}\end{array}$ & $\begin{array}{l}\mathbf{1 9 7 7 -} \\
\mathbf{1 9 8 1}\end{array}$ & $\begin{array}{l}\mathbf{1 9 8 2} \\
\mathbf{1 9 8 9}\end{array}$ & $\begin{array}{l}\mathbf{1 9 9 0} \\
\text { till } \\
\text { date }\end{array}$ \\
\hline Equality of Regions/ States & 50 & 50 & - & 40 & 40 \\
\hline Population & 50 & 50 & - & 40 & 30 \\
\hline Equal Access to Development Opportunities & - & - & 25 & - & - \\
\hline National Minimum Standard & - & - & 22 & - & - \\
\hline Absorptive Capacity & - & - & 20 & - & - \\
\hline Independent Revenue Efforts & - & - & 18 & 5 & 10 \\
\hline Fiscal Efficiency & - & - & 15 & - & - \\
\hline Social Development and Primary School enrolment & - & - & - & 15 & 10 \\
\hline Landmass and Terrain & - & - & - & - & 10 \\
\hline
\end{tabular}

Source: Danjuma T. Y. (1994) [10]; ICAN 2014 [6]

Table-9 and Figure-5 below contained the derivation formula for royalty's payment from 1946 till date.

Table-9: Revenue Allocation based on derivation from 1946 till date

\begin{tabular}{|c|c|c|c|c|c|c|c|c|c|c|}
\hline Year & 1946 & 1951 & 1970 & 1975 & 1977 & 1981 & 1984 & 1993 & 1999 & 2019 \\
\hline Percentage & 100 & 50 & 45 & 20 & 25 & 5 & 1.5 & 3 & 13 & 13 \\
\hline
\end{tabular}




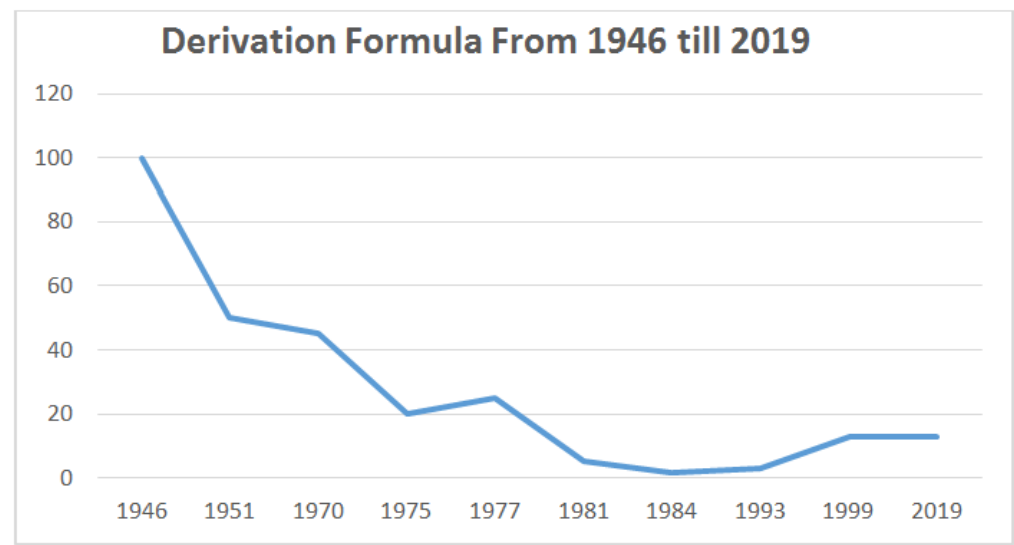

Fig-5: Derivation formula for Royalties payment from the Colonial era till Date

In 1946 Sir Arthur Richard the GovernorGeneral adopted the Phillipson Commission' recommended of $100 \%$ as the derivation formula while in 1951 Macpherson the then Governor-General adopted the Hick-Phillipson commission recommendation of $50 \%$. However, in 1970, after independence, General Yakubu Gowon who was the then Military Head of State reduce the royalties rent accruable to the state of oil exploitation to $45 \%$ and in 1975 General Murtala Mohammed sliced the derivation to $20 \%$. In 1977 General Olusegun Obasanjo increased the derivation insignificantly to $25 \%$. In 1981 the second republican President Alhaji Shehu Shagari worsen the situation by reducing it to 5\%. In 1984 Major General Muhammadu Buhari crashed it to its lowest ebb of $1.5 \%$, this was later improved upon by Major General Ibrahim Babangida government to an insignificant level of $3 \%$. The current derivation formula of $13 \%$ for the oil producing states was one of the 1995 constitutional conference recommendations. It was finally enshrined in Section 162(2) of the 1999 constitution. From the 1999 constitution, the 13\% Derivation provision is accounted for before the revenue is allocated into the federation account. On January, 2000, His Excellency Olusegun Obasanjo implemented the $13 \%$ derivation formula with a little twist of off-shore and off-shore dichotomy [12].

\section{Revenue Allocation and the Quest for Economic Development in Nigeria}

Every nation, state, region or area desires to take its people out of abject poverty and if possible give them decent life. This is the whole essence of economic development. Although it may difficult to eradicate poverty entirely, the focus has been on abject or extreme poverty. Relative poverty may continue to exist. It is abject poverty that deprives people of life sustenance (food, shelther, clothing and basic health care), freedom (from want,ignorance and squalor) and self-esteem (feeling of self-worth). Ensuring that people can sustain life, are free and have self-worth requires enourmous resources. In Nigeria, government revenues are such that they are derived majorly from natural resources. In exploiting these resources, so much damage is done to the environment of those areas and regions where these resources are deposited. The environmental damage has caused much pains and has greatly improverished the inhabitants of the areas.

In order to correct the ills associated with the environmental degradation and address the plights of the inbitants of the affected areas of the country, people have called for a more regional-responsive revenue allocation formula. In addition to this, people have called increased shares of the government revenue to the states and local government councils. This call is based on the notion that poverty is best tackled at the grassroot. This 'Grassroot poverty thoery' opines that it is the states and local government councils that are closer to the people and are, therefore, in better position to know their plight and address them. States and LG councils will be in better position to organize economic empowerment programmes that will directly impact on the economic lives of the people.

Moreso, it is the largeness of the share of the federal government that is responsible for unnecessary foreign trips by federal government officials thereby depriving the nation the needed fund to develop the economy.

\section{CONCLUSION AND RECOMMENDATIONS}

To achieve economic development and take people out of abject poverty and misery of life, more resources need to be given to the lower levels of government which are closer to the people. In addition, there is the need to reduce federal government share of the nation's revenue. Reducing the federal government share of the nation's revenue will reduce embezzlement, misappropriation and frivolous spendings at the federal level.

Based on the conclusion of this paper, the paper recommends that:

- The current agitation for full resource control is premature. At the current level of economic, political, social and psychological development of the nation, it will be difficult to manage resource control arrangement. A very salient issue in 
resource control is the basis of control - is it on the basis of region, state, local government area, tribe or ethnicity. There is need for caution so that the nation will not be plunged into tribal, civil or communal war

- While the current horizontal allocation formula may continue to be in force, there is need to review the current vertical allocation formula by reducing significantly the share of the federal government in the nation's revenue. This may however imply the transfer of some of the federal government fiscal functions (the non-strategic functions such as roads maintenance) to the states and local governments. This will enable government expenditure have direct impact on the people. In the light of this, we propose the following vertical formula

\begin{tabular}{|l|l|l|}
\hline Level & Current & Proposed \\
\hline Federal government & 52.68 & 30.60 \\
\hline State governments & 26.72 & 47.68 \\
\hline Local government & 20.60 & 21.72 \\
\hline
\end{tabular}

With $25 \%$ derivation

\section{REFERENCES}

1. Richard, A. O., \& Eme, O. (2015). State Governors and Revenue Allocation Formula in Nigeria: a case of the fourth Republic. International Journal of Accounting Research, 2(7), 14-36.

2. Bashir, M., Afzal, M. T., \& Azeem, M. (2008). Reliability and validity of qualitative and operational research paradigm. Pakistan journal of statistics and operation research, 4(1), 35-45.

3. Ahmed, I. (2019), Federal Government, State Government and Local Government Areas share \$619.857 billion in March, 2019 and $\$ 617.566$ billion in April, 2019. Available at www.prnigeria.com

4. Kabir, A. B. (2008), The Mechanics of Revenue Allocation: Understanding the Need for Effective
Data Collection and Management, Workshop Paper.

5. Nwidum, F. F. (2011). Federalism and Revenue Allocation in Nigeria: A Critical Evaluation of the Derivation Principle. Available at www.academic.edu

6. Institute of Chartered Accountants of Nigeria (ICAN). (2014). Fiscal Federalism and InterGovernment Fiscal Relations in Public Sector Accounting and Finance, Study Text, Lagos, Nigeria.

7. Arowolo, D. (2011), "Fiscal Federalism in Nigeria: Theory and Dimensions". International Journal of Science and Research Methodology, 9(4), 42-53.

8. Dorcas, A. O., \& Stanley, A. (2015). Fiscal Federalism and Development in Nigeria. Public Policy and Administration Research. 5(7), 36-44. Available at www.iiste.org.

9. Patrick, O. B. (2018), Fiscal Federalism and National Development in Nigeria. International Journal of Science and Research Methodology, 9(4), 42-53.

10. Danjuma, T. Y. (1994). Revenue sharing and the political economy of Nigerian federalism. The Nigerian Journal of Federalism,1(1), 43-68. Available at www.transcampus.org., www.ajol.info/journals/jorind.

11. Offiong, O. J. (2012), Nigeria Fiscal Federalism and Revenue Allocation Principles: Examining the contentiuos issues: edited by Imobighe, T. A., \& Ebohon, S. I. Themes and issues in Nigerian governance and politics: National Institute for Policy and Strategic Studies, Karu Plateau, Nigeria, 62-98

12. David, E. (2000). The Politics of $13 \%$ derivation Principle: A paper presented by the former Commissioner of Finance and Economic Planning, Edo State in Government House. Available at www.waado.org 